DOI: 10.1515/rpp-2016-0023

Instructor, OKTAY ALIYEV

Yuriy Bugay International Scientific and Technical University, Ukraine Address: 3 Magnitorskyi Psge, Kyiv, 02094, Ukraine

E-mail: Oktay_Kerim@ukr.net

\title{
EXPERIENCE OF FUTURE ECONOMISTS' SELF-STUDY ORGANIZATION IN FOREIGN HIGHER EDUCATION INSTITUTIONS
}

\begin{abstract}
The article consolidates information sources on the issues of future economists' self-study organization at foreign universities. There has been carried out the study of approaches to the interpretation of the term "self-study process" in the contemporary scientific thought abroad. There have been specified the productive ideas of foreign experience which are to be understood and implemented into practice of domestic higher education institutions in terms of professional training of future specialists in the field of social and behavioural sciences majoring in Economics, including the following: 1) student self-study is supposed to be a mandatory part of the educational process, with the amount of time dedicated to being less than 65 percent. At the same time a student-personalized approach to each student should be implemented and the course of study, specifics of the subject being learnt should be taken into account; the teachers are expected to offer verbal consulting and ICT support (including university web resources) of student self-study; 2) while organizing the educational process (syllabi, curricula for students of different educational levels) it should be taken into account that there is a link between self-education of future economists with his/her practical activities along with development prospects of the sector; 3) organization of future economists' self-study should be based on the student's conscious attitude to learning, recognition of its role in meeting the challenges and solving the urgent problems of economic education (motivational component); on knowledge forming the basis for the individual's self-study and determining his/her readiness for self-education in their future careers (cognitive component); on combination of skills and abilities of the individual, determining his/her functional readiness for professional self-education on challenging issues of economic sphere (operational and pragmatist component).
\end{abstract}

Key words: higher economic education, self-study organisation, productive ideas of foreign experience, professional training of future economists.

\section{INTRODUCTION}

The strategy of reforms to be clearly defined and prompted by the civil society, which is being actively formed in Ukraine, is an important incentive for accelerating systemic changes in all spheres of public life, especially the economy-related one. This leads to an intensive search for mechanisms to increase the level of professional training of future specialists in the field of social and behavioural sciences majoring in Economics in domestic higher education institutions.

Having considered the fact that the world trends in globalization, internationalization and Europeanization of the national system of economic education establish the actual priorities of this educational sphere, it is necessary to study foreign experience in professional training of future economists in higher education institutions (HEIs) so that its 
positive aspects can be taken it into account to increase the level of training of the specialists majoring in Economics in Ukraine.

We are to specify this scientific exploration's hallmark by the study of one of the important factors to ensure the quality of economic education at the universities of foreign countries, namely, the future economists' self-study organization in foreign higher education institutions.

\section{THE AIM OF THE STUDY}

The aim of the article is to synthesize the information sources on future economists' self-study organization in foreign higher education institutions and specify the productive ideas of foreign experience, which are to be understood and creatively implemented into practice of future economists' training in Ukraine. To achieve the above mentioned aims it is advisable, in our view, to focus on resolving the following tasks: to carry out the study of the approaches to the interpretation of the term "self-study" in the contemporary scientific thought abroad; to specify the productive achievements in the foreign experience in organization of future economists' self-study in foreign higher education institutions which can be implemented into the national practice of economic education taking into account the current challenges of economic development in Ukraine.

\section{THEORETICAL FRAMEWORK AND RESEARCH METHODS}

The theoretical basis of study on organization of student self-study in tertiary education institutions has encompassed modern scientific approaches (systemic, competence, pragmatic); concepts (of continuous professional education, personality-oriented education); principles (of student-centrism, promoting of self-fulfillment in the educational process; reliance on potential capabilities of the individual in self-gaining knowledge and skills).

Theoretical methods, in particular, comparison and juxtaposition of theoretical and practical approaches to identify productive ideas of foreign experience, requiring creative thinking and practical application to future economists' training in Ukraine have been chosen to be the leading research methods; theoretical and methodological analysis of information sources for the purpose of study of approaches to the interpretation of the notion of "self-study" in the contemporary scientific thought abroad.

\section{RESULTS}

To resolve the research problems it is advisable to carry out the study of native and foreign scholars' works on the approaches to the interpretation of the term "self study" in modern theory and practice of higher education. The works of such domestic and foreign scientists as V. I. Bobrytska, T. Goban-Klas, O. M. Nozhovnik, V. A. Petruk are of a particular scientific significance to our investigation creating theoretical framework for analyzing the problems of student self-study organization in higher economic education institutions in foreign countries. In particular, V. Bobrytska generalizing information sources on the questions in the research scope has concluded that there are several approaches to defining the essential content of the phenomenon "student self-study" in the foreign pedagogical literature.

Thus, in German pedagogy there are used such notions as "selbständige Arbeit" (self-study), "mittelbarer Unterricht" (mediated learning), "unmittelbarer Unterricht" (faceto-face learning) which are differentiated by the partially leading role of a teacher. In Pedagogy of Austria and Switzerland the widespread notion is "Stillarbeit" (silent work) that is the work done on one's own. The pedagogical science in France uses the term "le travail individual" (individual work) which means the work to be carried out without a teacher involved. In Pedagogy of Great Britain they use the notion "individual study" which has a dual meaning: the first one is the work to be carried out without a teacher involved and 
the second one is a face-to-face work of a teacher with a certain student. In US higher education institutions there is often used the concept of "independent study" which means a cognitive activity involving the students' work on their individual educational plans, curricula and their free choice in selecting tools and techniques to comprehend and process information. Interestingly, it is worth noting that according to UNESCO, the proportion of student independent work in the United States exceeds 65 percent (Бобрицька, 2011).

The study of the abovementioned works on the defined aspect of the problem enables us to discover that for psychological and educational literature of most European countries a characteristic feature is a relatively small number of scientific pieces and studies on the issue of tertiary students' self-education. In particular, O. Nozhovnik believes that individualism and personalism became an integral, generally accepted constituent of the philosophy of higher education in those countries (Ножовнік, 2009). The scientist's conclusion fully coincides with the inference of $\mathrm{V}$. Bobrytska indicating that at universities in most foreign countries students' self-study is the basis of their training whereas traditional forms of education (lectures, seminars, workshops) are only supposed to help students to organize their self-study (Бобрицька, 2011). Theoretically essential for our study is the conclusion of the scientist who suggests the author-owned approach to determining the essential content of the notion of a "self-study competence" regarded as a result of a person's self-learning which in its structure is a dynamic combination of knowledge, abilities and practical skills, ways of thinking, moral and ethical values and professional, philosophical and civic qualities (Бобрицька, 2015).

Summarising the foregoing we would like to emphasis on the fact that the lack of terminological consistency of the concepts of "self-study", "organization of self-study", "selfeducation" in Western scientific thought does not seem to be an obstacle for the practical realization of the students' autonomy in the educational process, but rather intensifies creative instructional work of teachers and students particularly in the field of economic education.

The study of foreign experience in organization of future economists' self-study indicates that this area of activity provides the highest level of expressing academic freedom for both teachers and students. In particular, according to specialization, materialtechnical facilities and qualifications of professors and teachers modern higher education institutions training future economists organize student self-study applying their own methods and learning models.

We are to begin the analysis of experience in organizing self-study of future economists in US higher education institutions that according to the world rankings traditionally occupy top places. Interestingly, at the universities of the United States student search work has come into a widespread use that creates a certain basis for deepening knowledge and improving skills in chosen areas of professional activity, developing skills of independent creative search in various fields of scientific knowledge, particularly in the economic sphere being extremely dynamic due to the rapid changes in high-tech production and business.

According to teachers and lecturers of the leading universities in the USA, it is search and independent work of students where such personality traits as leadership, creative thinking and the ability to build their own path of professional development are being revealed.

Independent educational and cognitive activity, according to American educators, is regarded as the only appropriate way to develop autonomous thinking, creativity, organizability, the ability to take responsibility (Петрук, 2008). Thus, student independent work at US universities has been accepted as an obligatory part of the educational process, 
which is also important to take into account when organizing the educational process at universities in Ukraine.

An interesting example of organizing student self-study at universities of Western Europe is the experience of Zaragoza University (Spain) based on M. Marco's methodology. According to this methodology the development of students' economic literacy is grounded on the application of cross-curricular connections involving Internet resources and the study of special terminology while self-learning.

In the view of the author's methodology, the content-based approach to independent learning of the professional communication language consists in the use of web quest (Marco, 2002). This approach is based on the content basis and application of authentic materials. It involves thorough consideration of students' individual needs in the study of economic terminology. This methodology has at least two advantages: first, students have the opportunity to work with authentic materials, so the result consists in the improvement a foreign language competency, and, secondly, in terms of academic competition (that is manifested during lessons) the motivation to better mastering internationally-used economic terminology learned during extracurricular time, i.e. during self-study, is formed.

It is worth noting that the effective approach to organization of students' self-study at the Jagiellonian University (Krakow, Poland), where methods of students' skills and abilities development to manage self-learning activities are effectively implemented.

It should be mentioned that in the last decade of the $21^{\text {st }}$ century there is a noticeable trend of Polish higher education transition to forms and technologies of independent learning covering at least 65 percent of class time.

The methodology of self-control combines the latest information tools of learning (Internet) and traditional forms of monitoring the results of students' learning (supervised by a teacher). Thus, the author of the methodology T. Goban-Klas (Goban-Klas, 2010) believes that self-control in the traditional system of learning is a means for students to verify their own abilities and skills acquired while learning a particular topic, discipline, to identify problematic issues, to resolve inconsistencies between residual and new knowledge, practical application of newly acquired knowledge.

The introduction of computer-based training programs (platforms) into the selfcontrol system improves its quality, provides all participants of the educational process with the current level of information literacy, academic adequacy in evaluation and assessment (self-evaluation and self-assessment) of students' educational achievements.

At the Polish University there has been developed a system of computer tests available on the Internet, through which students can test themselves, and the computer can assess their level of knowledge gained and skills acquired in the selected disciplines. It should be noted that the program "Autotest System" (System autotestyw) developed by Polish teachers is being implemented at the Jagiellonian University and other universities in the country. The system comprises the administration module (methodical guidelines for the application of the tests program), the module of providing students with services (module of students' registration, results of their tests), student database (lists of students according to speciality, year, group), database of tests, database of answers. The program is featured with an option to try alternative solutions in case of a negative result and the number of attempts is unlimited. The system considerably simplifies the supervisory work of teachers and increases the motivation of Polish students' self-learning activity.

As European practice of teaching students in tertiary education is traditionally based on students' self-study, we would like to apply to the basic trends in European Education specified by V. Bobrytska (Бобрицька, 2013), and consequently to outline the 
factors providing the ground for more effective organization of students' self-study in the national education systems of European countries.

We believe these are as follows: 1) acceleration of the development of global economies and as a result in modern higher education system there appears the need for training a new generation of professionals capable to build up their career in the rapidly changing labour market environment that requires systematic self-study of a professional; 2) diversification of types of educational programmes and the adoption of new educational standards, recognised by the participating countries of the Bologna process (the opportunity for an individual to obtain certain educational and scientific levels that will ensure his/her mobility in the market of economic services); 3) strengthening the relationship between the higher education institutions training economists and the labor market (formation of preparedness of the future professional to possible changes in the occupational activity, to self-update knowledge, to acquire new skills, etc.); 4) the dynamic development of the world economy, the growth of international competition, reducing the scope for unskilled and low-skilled labour, deep structural changes in the sphere of economic employment which determine the constant need for on-job professional development and retraining of specialists in the system of formal, non-formal and informal economic education. Undoubtedly, the outlined factors should be considered in higher economic education of Ukraine, which will allow it to more quickly join the European Higher Education Area.

European practice of students' self-study organization in tertiary education has greatly influenced other national education systems in the world that are developing rapidly. Here is an example: in the West there is such a kind of students' self-learning as learning of a professional economical language via project technology using a computer (Project-Based Computer Assisted Language Learning: PBCALL).

Thus, during the educational process in the United Arab Emirates (UAE), in particular, at the University of the Middle East (Zayed University), there is applied the educational technology of projects with the use of Internet resources as a basis Arabic method of students' self-study organization.

Based on this kind of training activity there has been developed and is being implemented into practice the method of Web-project training at other universities in UAE. The essence of this method is that students create web pages based on existing paper and electronic materials, at the same time acquiring and developing the skills of analysis, selection of media (paper and electronic), planning and fulfilling the project in accordance with the teacher's assignment. Under this methodology, students can exercise self-control of the results of their activity, along with the possibility of authentic communication. Practical purposefulness of the assignment turns the project to be fulfilled into an effective model of increasing motivation to study, enhances erudition of the future professionals etc. The author of the method E. Kayser (Kayser, E., 2002) notes that the more overarching goal of the project is, the more actively the student is working on it.

We cannot ignore initiatives launched concerning the training of future economists at universities of Azerbaijan. Significant potential for students to acquire skills of individual research and learning has the SABAH project, which in Azeri means "tomorrow". The meaning is hidden in each letter: SA - savadlı (translated as "literate"), BA - bacariglı ("capable"), $\mathrm{H}$ - hazıriglı ("trained").

The project is a pilot and involves 7 universities in Baku with 34 most popular professions, including есоnomic one (Мурадов, 2013). It should be pointed out that the $\mathrm{SABAH}$ project creates such a learning environment establishing a real basis for the 
transition to such levels of students' self-study organization when they gain the ability to autonomously build up a navigation of search learning resources to develop skills of selfeducation, self-improvement, professional self-development during the period of obtaining future profession.

\section{CONCLUSIONS}

Synthesis of information sources on the issues of future economists' self-study organization at foreign universities enables specification of productive ideas of foreign experience requiring creative thinking and practical application into the training process of specialists in economics in Ukraine. In our opinion, the following ideas are worthy considering:

1. Students' self-study should be a mandatory part of the educational process with the amount of time dedicated to be not less than 65 percent. In this context there should be implemented a personalised approach to each student, the year of study and specificity of academic disciplines should be taken into account, teachers have to offer verbal consulting and ICT support (involving web resources of universities) of students' self-study.

2. In the organization of the educational process (syllabi, curricula for students of different educational levels) there should be taken into account the link between future economists' self-education and his/her practical work, the prospects of the industry.

3. Compilation and scheduling of future economists' self-study should be based on students' conscious attitude to learning recognising its role in solving the urgent problems of economic education (motivational component); knowledge forming the basis of selfeducation, determining his/her preparedness for self-education in their future careers (cognitive component); the combination of the person's skills that determine his/her functional preparedness for specialism-related self-education as urgent issues of economic sphere (business and activity component) are considered.

We incline to estimate the research of technologies forming future economists' skills of exercising self-control and self-assessment of the results of their educational and professional activity to be among the prospective areas for the future scientific studies, application of the potential of informal education for self-education, self-improvement and professional fulfilment.

\section{REFERENCES}

1. Eurydice. (2010). Focus on Higher Education in Europe in 2010: The Impact of the Bologna Process. Retrieved 23.05.2016 : http://www.Eurydice.org.

2. Goban-Klas, T. (2010). Samokontrola postępów w nauce z wykorzystaniem Internetu [Self-monitoring of Academic Progress Using the Internet]. Retrieved 23.05.2016 from : http://www.if.uj.edu.pl.

3. Kayser, E. (2002). Creating Meaningful Web Pages : a Project-based Course. Forum, Volume 40, No 3, pp. 12-18.

4. Marco, M. J. L. (2002). Internet Content-based Activities for English for Specific Purposes. Forum, Volume 40, No 3, pp. 20-25.

5. Бобрицька, В. І. (2013). Мобільність як ключовий принцип формування європейського освітнього простору [Mobility as a Key Principle of Forming European Educational Area]. Вища освіта Украӥни [Higher Education of Ukraine], No 3, pp. 234-238 (in Ukrainian). 
6. Бобрицька, В. І. (2011). Організаційно-педагогічні умови формування самоосвітньої компетенції педагога вищої школи [Organizational and Pedagogical Conditions of Forming Self-educational Competence of the Teacher in Tertiary Education]. Науковий часопис НПУ ім. М. П. Драгоманова [Scientific Annals of NPU named after M. P. Drahomanov], Volume 5, pp. 55-58 (in Ukrainian).

7. Бобрицька, В. I. (2015). Професійно орієнтований контекст формування самоосвітньої компетентності майбутнього викладача в умовах магістратури [Professionally-oriented Context of Forming Self-educational Competence of a Future Teacher in the settings of Master's Degree]. Вісник начіонального авіаиійного університету [Journal of The National Aviation University], Volume 2 (7), pp. 24-30 (in Ukrainian).

8. Мурадов, А. (2013). Образование не может развиваться без инноваций [Education cannot Develop without Innovation]. Retrieved 23.05.2016 from : http://unec.edu.az/ rektor-edalel-muradovun-word-economics-jurnalina-musahibesi/.

9. Ножовник, О. М. (2009). Компаративний аналіз вітчизняного та зарубіжного досвіду формування самоосвітньої компетенції майбутніх фахівців у галузі зовнішньоекономічної діяльності у процесі вивчення іноземних мов [Comparative Analysis of Domestic and Foreign experience in Forming Self-educational Competence of future specialists in international economics in the process of foreign languages learning]. Постметодика [Postmetodology], No 7 (91), pp. 58-62 (in Ukrainian).

10. Петрук, В. А. (2008). Теоретико-методичні засади формування базових професійних компетенцій у майбутніх фахівців технічних спеціальностей [Тheoretical and Methodological Foundations for the Formation of Basic Professional Competencies of Future Professionals in the Technical Fields]. Abstract of a Thesis for Doctoral Degree. Національний педагогічний університет імені М. П. Драгоманова, 40 р. (in Ukrainian). 